\title{
The discovery of seven engraved La Tène glass beads from the sanctuary of Mathay-Mandeure
}

Joëlle Rolland $^{1, *} \&$ Laurent Olivier $^{2}$

Analysis of seven newly discovered engraved La Tène beads from the Mathay-Mandeure sanctuary in Doubs, France, has refined the chronology for the manufacture of such rare artefacts, and increases our understanding of Late Iron Age ritual deposition practices.

Analysis of 89 European Iron Age glass objects from the Mathay-Mandeure Celtic sanctuary in Doubs, France, has led to the discovery of seven previously unnoticed La Tène engraved glass beads. Evidence for the Late Iron Age working of cold glass is extremely rare, with only a single Celtic engraved glass bead known from the Müsingen-Rain cemetery in Switzerland (Gambari \& Kaenel 2001). Examination and elemental analysis of the objects increases our understanding of the depositional practices carried out at the Mathay-Mandeure sanctuary. The discovery also encourages greater attention to the potential of glass beads as a medium for bearing engravings.

Excavations carried out by Clément Duvernoy (1883) at the monumental sanctuary of 'Clos du Château' between 1882 and 1883 yielded almost a tonne of melted Gaulish coins. This prompted a series of unofficial excavations, particularly by local antiquarian Aimé Péquignet. Beneath a Roman landfill level, Aimé Péquignet discovered a large pit containing many artefacts. Although glass items predominated, the assemblage also contained iron objects, bronze ornaments (including two zoomorphic figurines), coins, ceramic vessels and gold artefacts. Of the glass finds, 356 beads, 147 bracelets and a dozen other items are now housed in the National Museum of Archaeology in Saint-Germain-en-Laye.

The glass assemblage is composite in nature, comprising a mixture of worn glass objects, dating from the La Tène C2 period (200-150 BC) and homogeneous sets of La Tène D period (150-25 BC) beads (Guillard 1989; Bride 2000; Barral 2009). In terms of form, the similarity of these La Tène $\mathrm{D}$ bead sets is such that some of them were probably made at the same time, by the same craftsperson. The absence of wear traces on these sets suggests a very short interval between their manufacture and their deposition. The composite nature of the deposit is also observed on the seven engraved beads. The two amber and purple glass beads (52491.378 and .440) are characteristic of the La Tène D period (Haevernick 1960; Gebhard 1989) (Figure 1). The remaining colourless beads can be divided into four different

1 University of Paris 1, Panthéon-Sorbonne, UMR 8215 Trajectoires, UMR 5060 IRAMat/Ceb, 21 allée de l'Université, 92023 Nanterre, France

2 Department of Celtic and Gallic Archaeology, National Museum of Archaeology, Saint-Germain-en-Laye (France), UMR 7324 CITERES, Chàteau-Place Charles de Gaulle 78105 Saint-Germain-en-Laye cedex, France

* Author for correspondence (Email: joelle.rolland@mae.univ-paris1.fr)

(c) Antiquity Publications Ltd, 2018 ANTIQUITY 92 364, e6 (2018): 1-7 
types, according to their profile shape and the presence of an inner layer of yellow glass (Figures 2-4). These types were produced at the end of the La Tène C2 period, but also during the La Tène $\mathrm{D}$ period. Our elemental analysis, however, has allowed us to refine the chronology for the manufacture of these beads further.

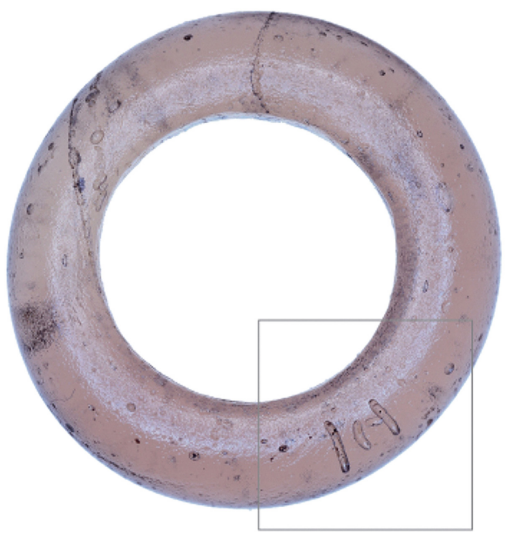

Mathay-Mandeure MAN 52491440

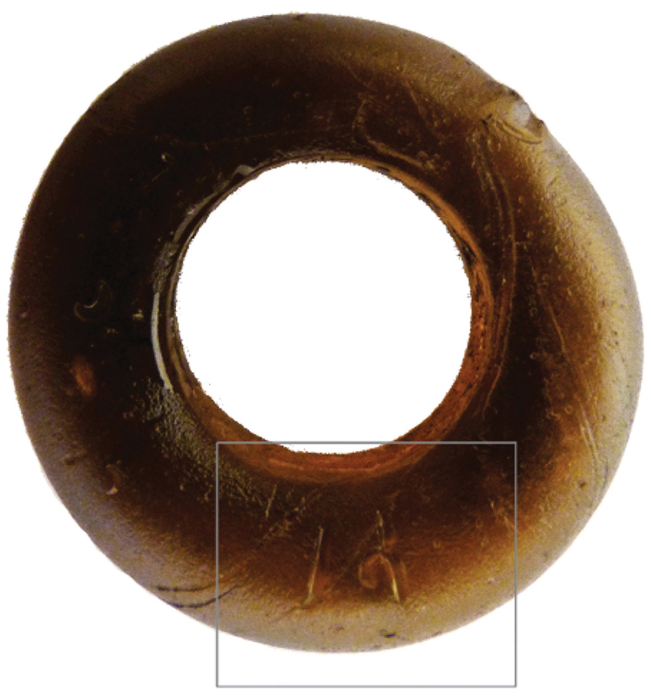

Mathay-Mandeure MAN 52491378
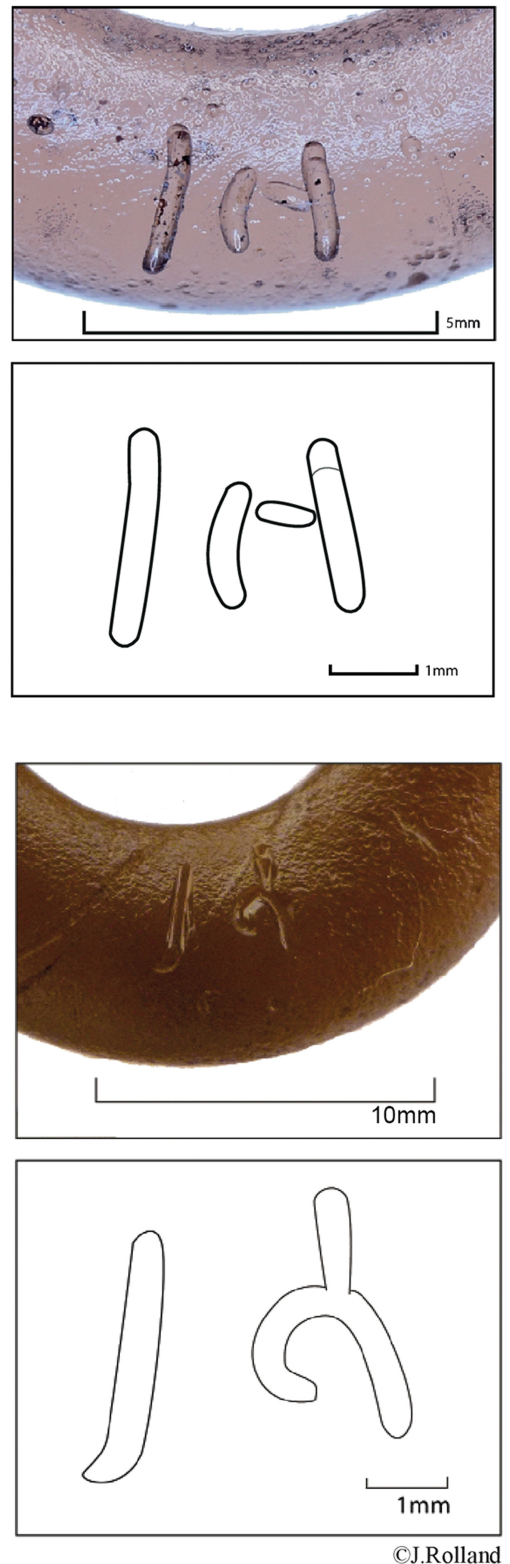

\section{Scale $3: 1$}

Figure 1. Engraved beads $n^{\circ} 52491.440$ and .378 from the Mathay-Mandeure sanctuary (National Museum of Archaeology in Saint-Germain-en-Laye, images by J. Rolland).

(C) Antiquity Publications Ltd, 2018 

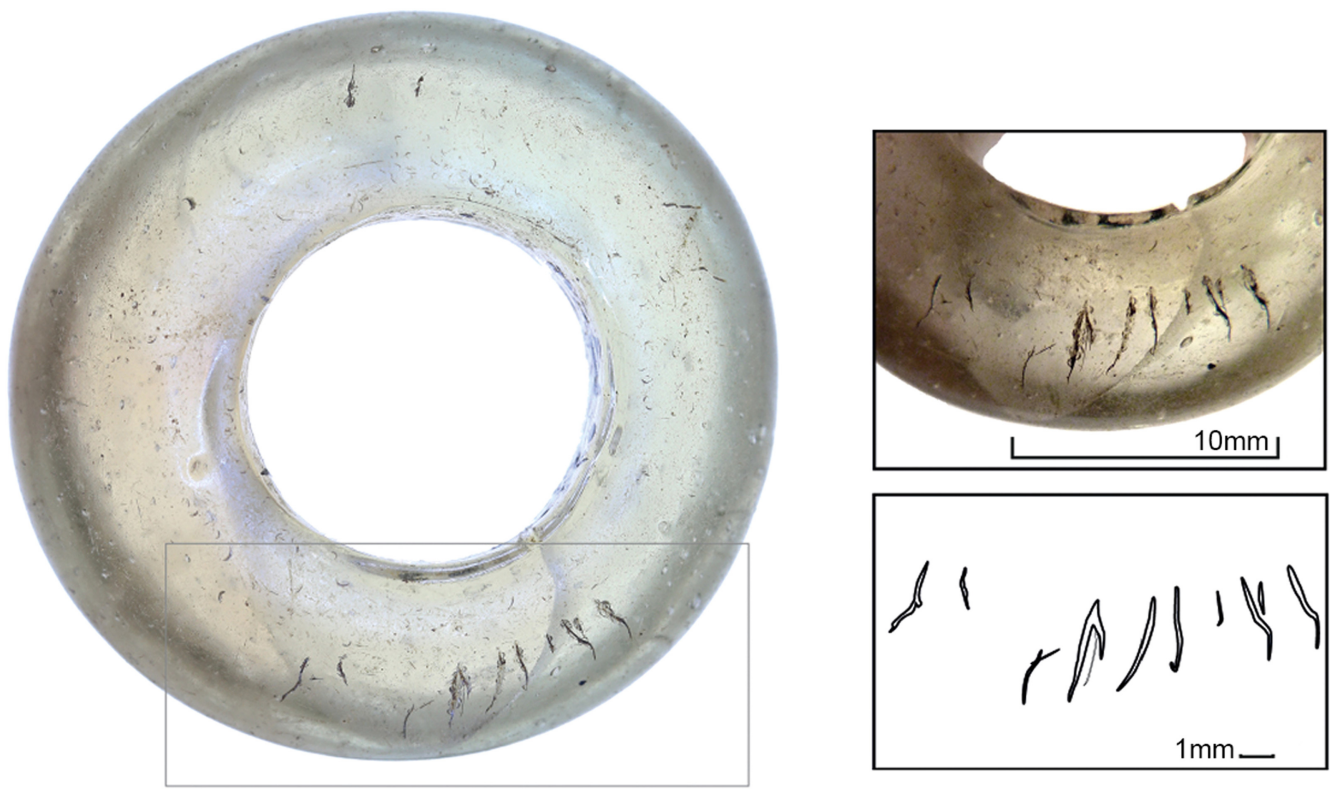

Mathay-Mandeure MAN 52491460
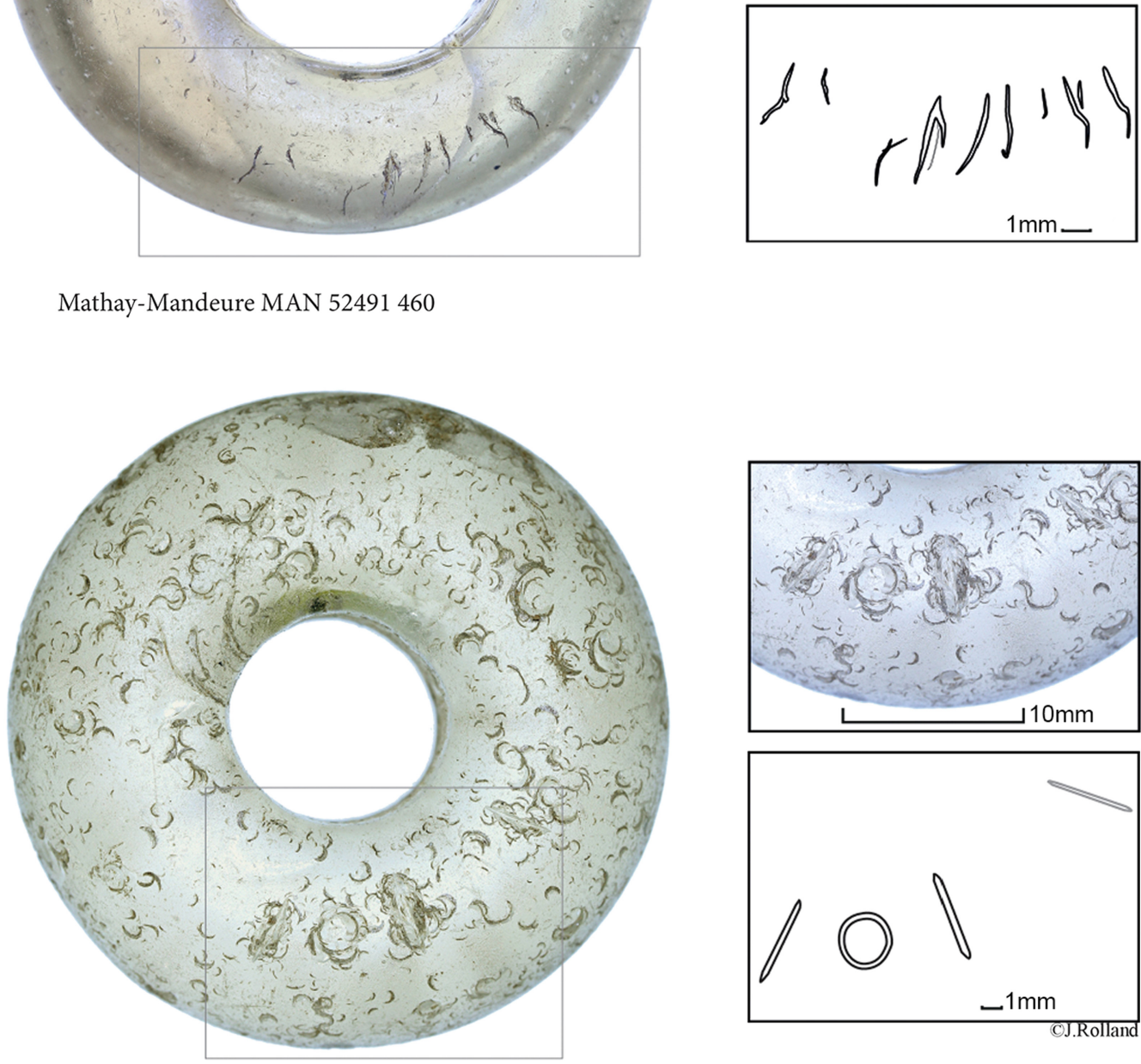

Mathay-Mandeure MAN 52491473
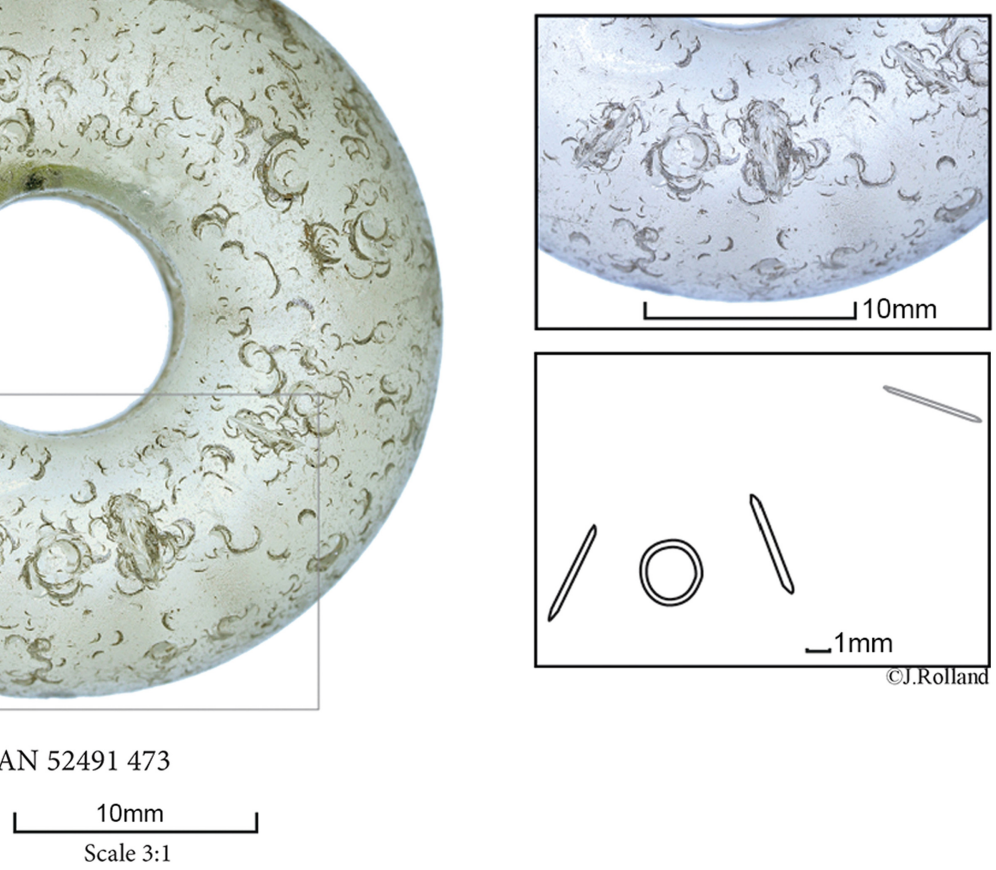

Figure 2. Engraved beads $n^{\circ} 52491.460$ and .473 from the Mathay-Mandeure sanctuary (National Museum of Archaeology in Saint-Germain-en-Laye, images by J. Rolland). 

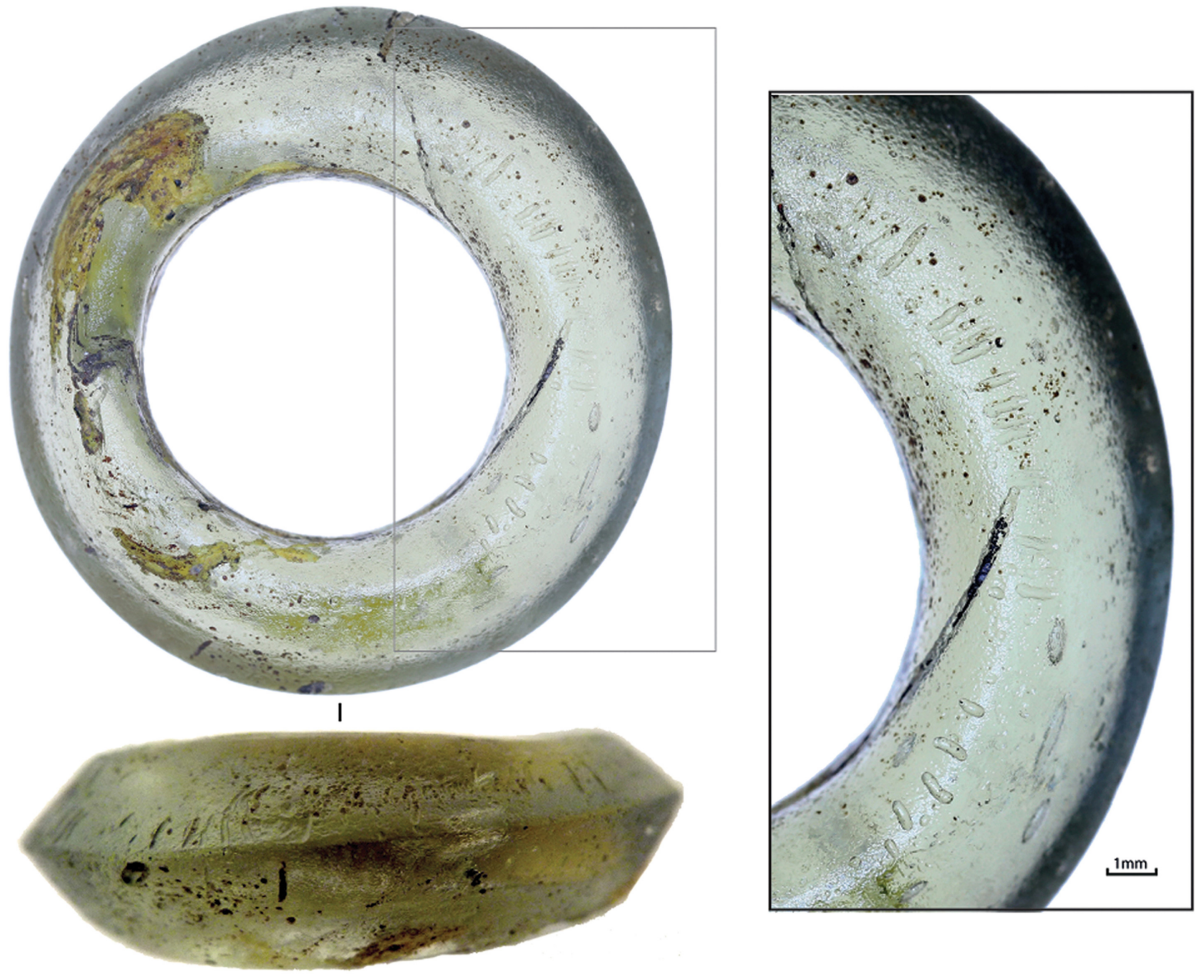

Mathay-Mandeure MAN 52491465

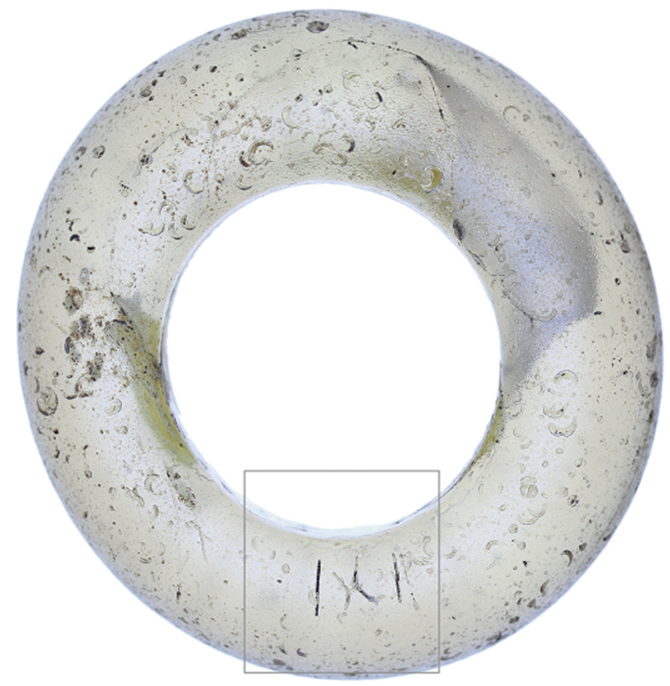

Mathay-Mandeure MAN 52491475
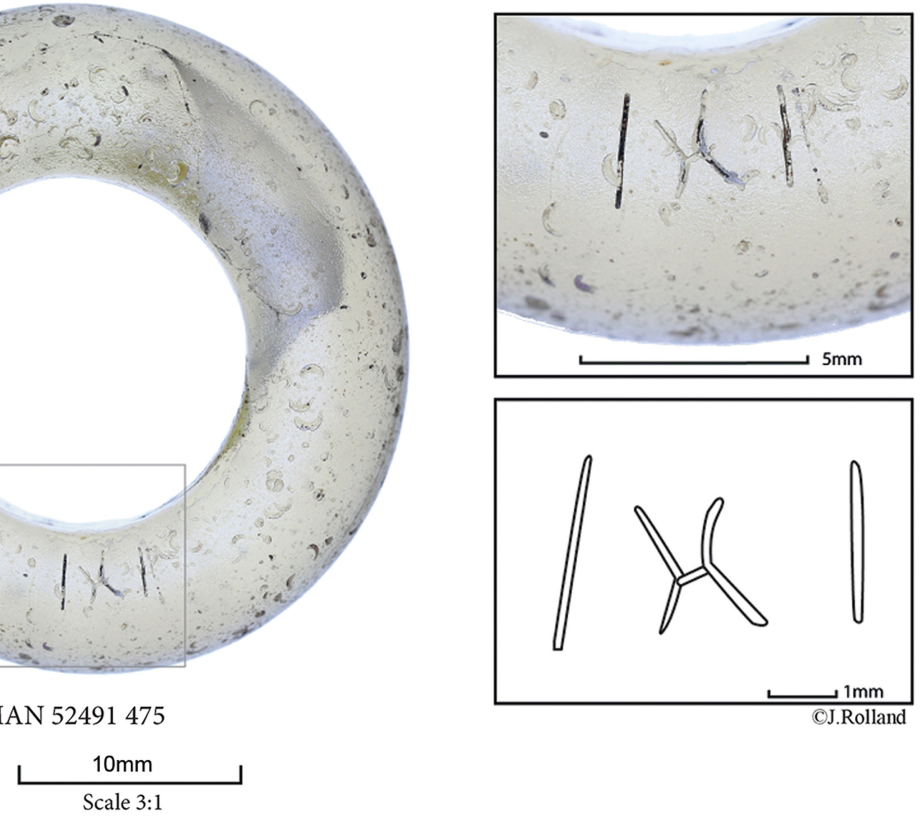

Figure 3. Engraved beads $n^{\circ} 52491.465$ and .475 from the Mathay-Mandeure sanctuary (National Museum of Archaeology in Saint-Germain-en-Laye, images by J. Rolland).

(C) Antiquity Publications Ltd, 2018 

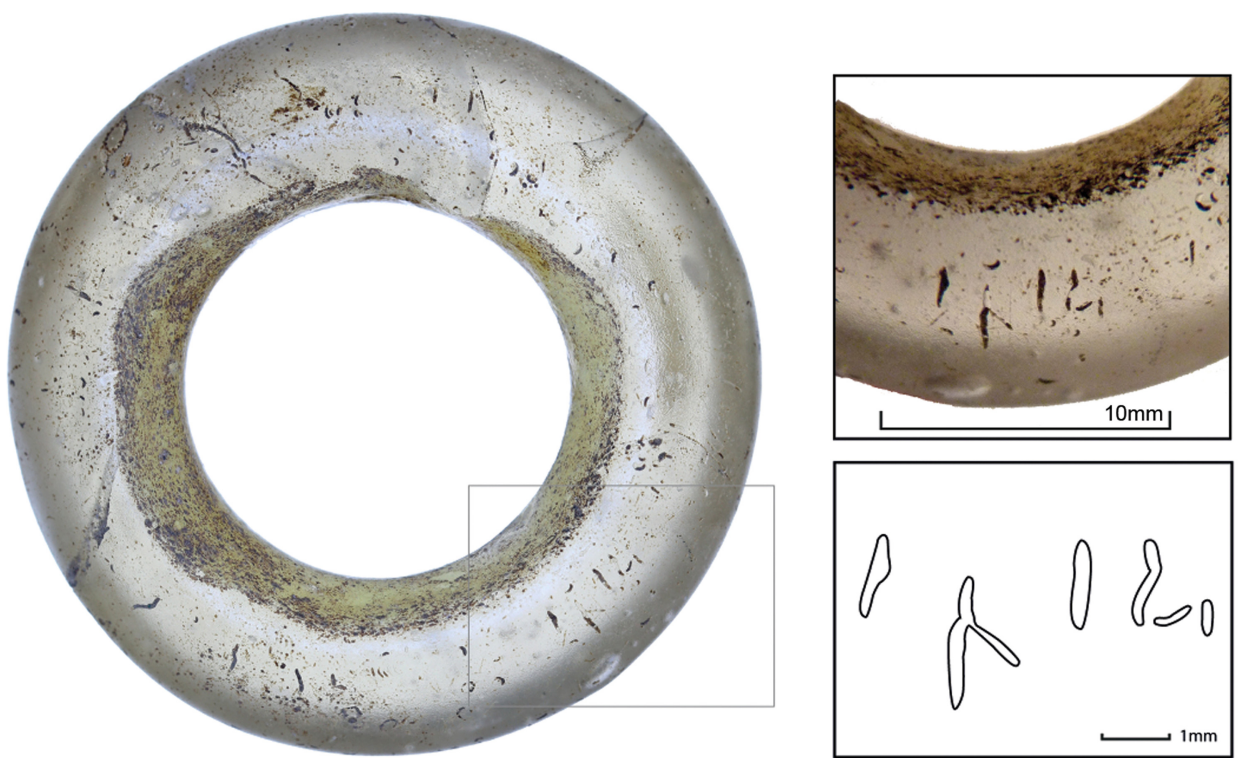

Mathay-Mandeure MAN 52491464
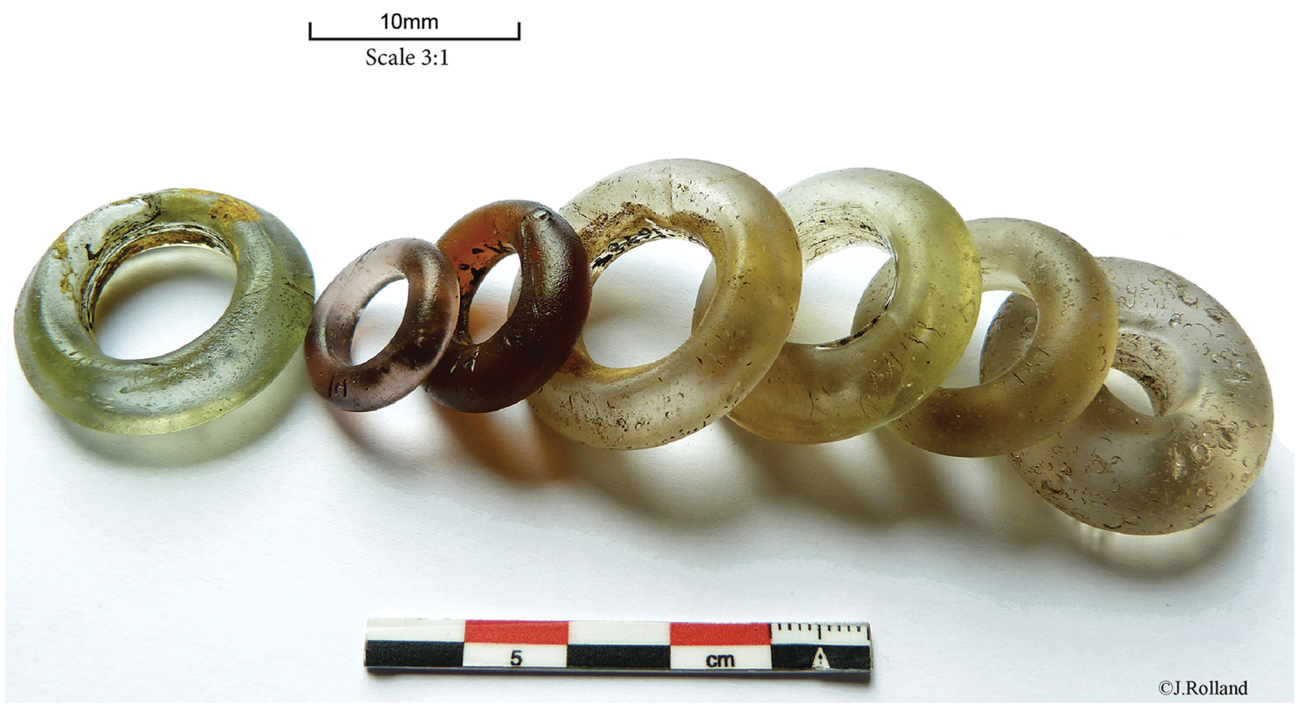

Figure 4. Top) engraved beads $n^{\circ} 52491.464$ from the Mathay-Mandeure sanctuary; bottom) the seven engraved beads (National Museum of Archaeology in Saint-Germain-en-Laye, images by J. Rolland).

To identify major, minor and trace elements (Gratuze 2016), the seven engraved beads from Mathay-Mandeure were analysed using a LA-ICP-MS (mass spectrometer) at the CNRS, IRAMAT/CEB, in Orleans, France. Analysis reveals that all samples comprise sodalime glass, using a mineral source-Natron—as the soda flux (Figure 5). Published data (Karwowski 2004) and recent results (Rolland 2017) show that La Tène C2-and La Tène D-period mineral-natron glass is characterised mainly by low zirconium and high strontium contents, the mark of the Levantine origin of the sands used (Nenna \& Gratuze 2009; 


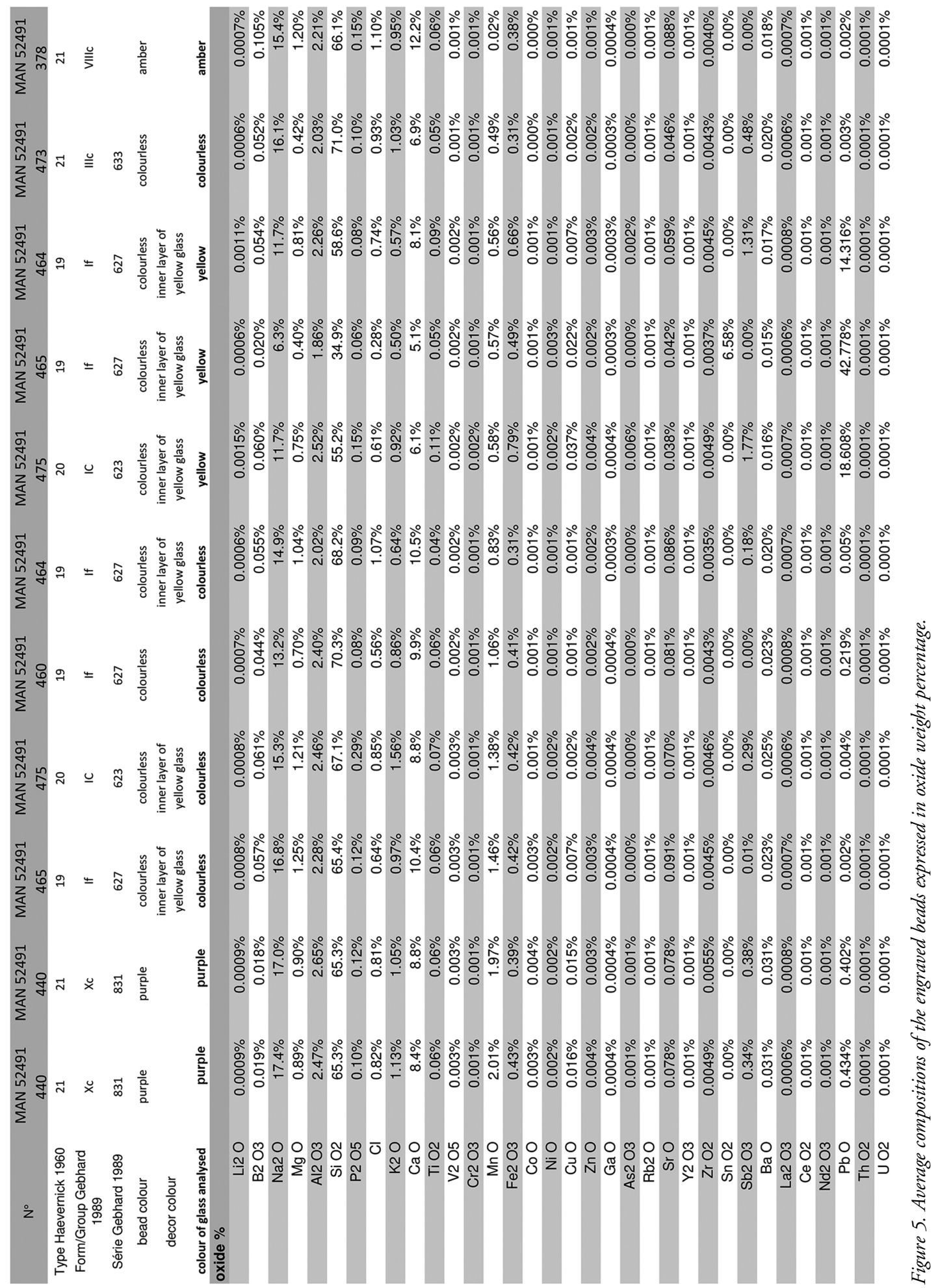

(C) Antiquity Publications Ltd, 2018 
Rolland 2017). Furthermore, the manganese content of all La Tène glass generally increased over time (Huisman et al. 2017; Rolland 2017). The lower manganese content of bead 52491.473 from Mathay-Mandeure suggests that it could be the oldest of the seven. Covered with traces of wear, this bead was probably worn before its deposition (Figure 2). The engraving on the bead, however, resembles those on beads 52491.378, .440 and .475. Therefore, while bead .473 appears to have been manufactured at an earlier date, the engraving was probably added at the same time as the other engravings-perhaps specifically for the purpose of deposition.

The Mandeure deposit and the presence of glass objects in other sanctuary contexts suggest that these valuable objects were discarded as part of ostentatious social practices. As with the glass bead from the Müsingen-Rain cemetery, the Mandeure engravings appear to use a Lepontic or Insubro-Lepontic script. The deciphering of such engravings will undoubtedly open interesting avenues for future research.

\section{Acknowledgements}

The authors thank Bernard Gratuze for his collaboration in the analysis of the beads, and Thomas Markey for his research on the inscriptions.

\section{References}

BARral, P. 2009. Les dépôts du sanctuaire de Mandeure, in M. Honegger (ed.) Le site de La Tène: bilan des connaissances. Actes de la Table ronde internationale de Neuchâtel, 1-3 novembre 2007 (Archéologie neuchâteloise 43): 185-96. Hauterive: Office du patrimoine et de l'archéologie de Neuchâtel.

BRIDE, A.-S. 2000. La parure celtique en verre au deuxième âge du Fer dans l'est de la Gaule. Bulletin de l'AFEAF 18: 50-1.

Duvernoy, C. 1883 . Note sur une enceinte récemment découverte à Mandeure. Mémoires de la Société d'Émulation de Montbéliard 1883 (II):114-27.

Gambari, F.M. \& G. Kaenel. 2001. L'iscrizione celtica sulla perla da Münsingen: una nuova lettura. Archäologie der Schweiz 24: 34-37.

GebHard, R. 1989. Der Glasschmuck aus dem Oppidum von Manching (Die Ausgrabungen in Manching 11). Stuttgart: F. Steiner Verl.

Gratuze, B. 2016. Glass characterization using laser ablation-inductively coupled plasma-mass spectrometry methods, in L. Dussubieux, B. Gratuze \& M. Golitko (ed.) Recent advances in laser ablation ICP-MS for archaeology: 179-96. Berlin \& Heidelberg: Springer. https://doi.org/10.1007/978-3-662-49894-1_12
Guillard, M.-C. 1989. La verrerie protohistorique de Mandeure (Doubs), in M. Feugère (ed.) Le verre préromain en Europe occidentale: 145-52. Montagnac: Éditions Monique Mergoil.

HaEvernick, T.E. 1960. Die Glasarmringe und Ringperlen der Mittel- und Spätlatènezeit auf dem europäischen Festland. Bonn: R. Habelt.

Huisman, D.J., J. Van Der LaAn, G.R. Davies, B. J.H. Van Os, N. Roymans, B. Fermin \& M. KarwowsKi. 2017. Purple haze: combined geochemical and $\mathrm{Pb}-\mathrm{Sr}$ isotope constraints on colourants in Celtic glass. Journal of Archaeological Science 81: 59-78. https://doi.org/10.1016/j.jas.2017.03.008

KaRwowsKi, M. 2004. Latènezeitlicher Glasringschmuck aus Ostösterreich. Wien: Österreichischen Akademie der Wissenschaften.

Nenna, M.-D. \& B. Gratuze. 2009. Étude diachronique des compositions de verre employées dans les vases mosaïqués antiques: résultats préliminaires, in K.H.A. Janssens \& P. Degryse (ed.) Annales du 17e Congrès de l'Association Internationale pour l'histoire du verre: 199-205. Anvers: University Press Antwerp.

Rolland, J. 2017. L'artisanat du verre dans le monde celtique au second âge du Fer: approches archéométriques, technologiques et sociales. Unpublished $\mathrm{PhD}$ dissertation, Université Paris 1-Panthéon-Sorbonne. 